
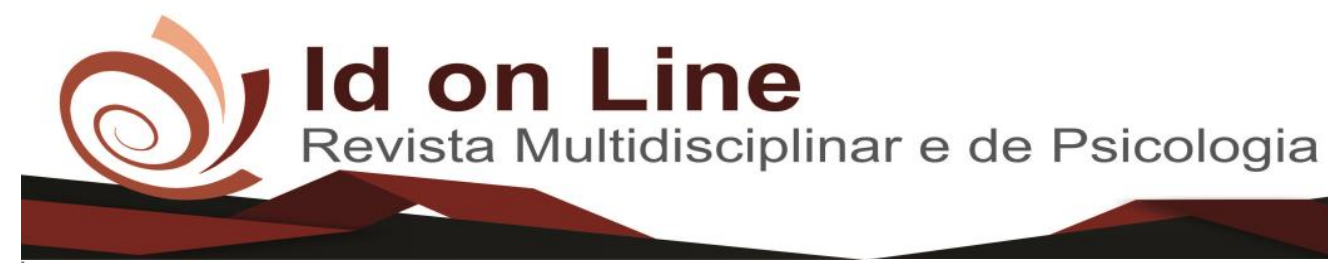

DOI: 10.14295/idonline.v14i50.2418

Artigo

\title{
Projeto Escola Sem Partido: Uma roupa velha que não nos serve mais
}

\author{
Arnóbio Rodrigues de Sousa Júniorl ${ }^{1}$, Antonio Avelar Macedo Neri², \\ Maria das Dores Alexandre Maia ${ }^{3}$ e Mayara Barros Bezerra ${ }^{4}$
}

\begin{abstract}
Resumo: A presente produção acadêmica tem como objetivo central analisar o Projeto Escola Sem Partido e suas implicações no cerceamento da discussão de gênero e orientação sexual na sala de aula. Este Projeto usa os espaços educativos para protagonizar suas vertentes conservadoras em contraponto a dimensão de uma pedagogia libertadora. Nesse sentido, a pesquisa subsidia-se em natureza qualitativa de cunho bibliográfica além da pesquisa documental com base no Projeto de Lei ${ }^{\circ}$ 2474/14 do deputado Flávio Bolsonaro e na Lei de Diretrizes e Bases da Educação (LDB). É evidente o enfoque conservador e alienante do Projeto Escola Sem Partido que se contrapõe a liberdade de ensinar e a práxis pedagógica no sentido da formação crítica e do empoderamento dos educandos. Assim, nota-se a retórica a favor da educação neutra e das narrativas antigênero em um discurso contrariamente as escolas democráticas e a desbarbarização da educação.
\end{abstract}

Palavras-Chaves: Projeto Escola Sem Partido; Identidade de Gênero-Orientação Sexual;

Despolitização da Educação.

\section{Escola Sem Partido Project: An Old Clothing That Doesn't Fit Us Anymore}

\begin{abstract}
The present academic production has as main objective to problematize the Escola Sem Partido Project and its implications in curbing the discussion of gender and sexual orientation in the classroom. This Project uses educational spaces to star in its conservative strands in counterpoint to the dimension of a liberating pedagogy. In this sense, the research is based on a qualitative nature of bibliographic nature in addition to documentary research based on the Project of Law No. 2474/14 of Deputy Flávio Bolsonaro and the Law of Directives and Bases of Education (LDB). It is evident the conservative and alienating approach of the Escola Sem Partido Project that opposes the freedom to teach and the pedagogical praxis in the sense of critical education and the empowerment of students. Thus, there is a rhetoric in favor of neutral education and anti-gender narratives in a discourse contrary to democratic schools and the disarming of education.
\end{abstract}

Keywords: Escola sem Partido Project; Gender Identity-Sexual Orientation; Depoliticization of Education.

\footnotetext{
${ }^{1}$ Instituto Federal de Educação, Ciência e Tecnologia do Ceará Campus Crateús. arnobiojr07@gmail.com;

${ }^{2}$ Instituto Federal de Educação, Ciência e Tecnologia do Ceará Campus Crateús. avelarmacedo5 @gmail.com;

${ }^{3}$ Instituto Federal de Educação, Ciência e Tecnologia do Ceará Campus Crateús;

${ }^{4}$ Instituto Federal de Educação, Ciência e Tecnologia do Ceará Campus Crateús.
} 


\section{Introdução}

Em tempos de crise e alijamento das políticas educacionais em que vivemos nesta segunda década dos anos 2000, a retórica e as teses do Projeto Escola Sem Partido - ESP devem ser discutidas em todos os espaços educativos de formação política, social e humana para que possamos compreender suas ideologias e propostas de formação alicerçadas na pedagogia da

mordaça. É sabido que este projeto apoiado na atual conjuntura pelos arautos do golpe de 2016 é ilegítimo, pois atenta a formação crítica, as perspectivas de ensino democrático e a liberdade de ensinar. Assim, as discussões no que tange a política deste projeto está embasada nos monopólios das mídias sociais como ferramentas da violência simbólica sendo pouco discutido nos contextos escolares e nas universidades uma vez que este projeto, a priori, pouco apresenta legitimidade de formação educacional.

No entanto, é visível que as vertentes ideológicas deste projeto estão crescendo substancialmente através de um viés conservador, reacionário e se apoiando nas mídias sociais como instrumentos de persuasão do discurso conservador e divulgação de suas concepções ideológicas e políticas contra as perspectivas de escolas democráticas, contra a liberdade de ensinar e contra a formação de cunho político e cultural. É visto que as concepções deste movimento reacionário e conservador aponta para o naufrágio educacional e para a reprodução da ordem social. As propostas pedagógicas e políticas deste projeto se alinham a uma tendência neoliberal, tendo em vista sua criação a favor do empreendedorismo da barbárie educacional, a favor da efetivação da educação como insumo econômico e contra a educação democrática de inclusão social e de formação de seres politizados.

Nesse sentido, as narrativas ludibriosas do ESP vem ganhando espaço desde 2004, a partir de sua criação por meio de forças políticas reacionárias centrado na figura do advogado Miguel Nagib, um dos idealizadores e fundadores do projeto. Assim, cabe aos profissionais da educação levantar as discussões acerca deste projeto e perceber os novos mecanismos de atuação que corrobora com o sucateamento da educação como política pública. Sem dúvidas, o projeto escola sem partido caminha em direção ao autoritarismo e em conjunto com as lógicas gerenciais da educação para o capital, afinal, seu cunho pedagógico criminaliza a vertente epistemológica defendida por Paulo Freire.

“Nessa perspectiva, o debate do projeto 'Escola Sem Partido' vem de encontro com os reais objetivos da escola dominante que prega um ensino nitidamente colonizador, historicamente voltado para o interesse mercantil e, consequentemente, do capital". (JÚNIOR 
et al., 2020a, p. 50). Partindo deste pressuposto, a ideologia educacional do ESP viabiliza uma perspectiva de ensino colonial onde não há o interesse da formação crítica nem de questionar a legitimidade da ordem dominante e suas políticas de dominação social. Contudo, enquanto sujeitos históricos e atores sociais devemos problematizar e questionar pois "nenhuma "ordem" opressora suportaria que os oprimidos passassem a dizer: “por quê?”. (FREIRE, 2014, p. 43). É nesse sentido que o presente artigo anuncia a discussão acerca do projeto escola sem partido objetivando analisar suas teorias ao passo que possibilita o questionamento sobre seus princípios epistemológicos enviesados na pedagogia como formação acrítica e de (neo) colonização.

Nota-se que o projeto escola sem partido é, em suma, uma ferramenta de dominação em massa pois usa o discurso da neutralidade e toma posse do termo "sem" como forma de ludibriar toda a camada social usando uma retórica persuasiva e sem caráter de emancipação humana. É falsa as narrativas do ensino humanístico e a preocupação com a transformação social visto que suas bases pedagógicas e políticas são asseguradas pela bancada evangélica, nos defensores da cura gay, nos que saudam a ditadura militar e enraizadas, sobretudo, em um único partido político, o da mordaça e do autoritarismo que criminaliza autores que objetivam o pensar criticamente.

\begin{abstract}
A atual geração dos mitos e seu projeto colonial alienante usa a escola, assim como outras ferramentas da educação, contra professores que defendem a educação com viés libertador, atacando concomitantemente figuras como Freire, Marx e Gramsci. Isso está claro com as tentativas de boicote à educação e de aplicação do projeto de lei Escola Sem Partido, por conseguinte, criando teorias da conspiração como o Marxismo Cultural e a Ideologia de Gênero. (SOUSA JÚNIOR et al., 2020b, p. 141).
\end{abstract}

Nesse sentido, é necessário a problematização na perspectiva da desconstrução desse pensamento alienante, fixo no capital e financiado pelos monopólios de órgãos multilaterais. Levando em conta a farsa de sistema democrático a qual vivemos, a presente produção acadêmica oportuniza levantar a discussão das concepções políticas do escola ESP.

De fato, necessita-se da pedagogia da indignação e da libertação para que possamos perceber quem está por traz das políticas educacionais e como essas simbologias reacionárias estão consolidadas na escola. A rebeldia dos oprimidos só é possível mediante escolas democráticas e uma educação que coloca o sujeito como ator social e com autonomia intelectual. Os princípios pedagógicos do ESP não vão de encontro com a emancipação humana.

Por isso, é de suma importância pautar a discussão de forma contra hegemônica pois como nos diz Gadotti (2010, p. 66) “o diálogo proposto pelas elites é vertical, forma o 
“educando-massa", impossibilitando-o de se manifestar". É nesse sentido que a concepção pedagógica do ESP está sendo pautada nas escolas e quando possível em outros espaços educativos a fim de amordaçar o aprendiz e essencialmente o educador.

Contra a domesticação à leitura, o artigo pauta também a discussão para uma perspectiva democrática, de explicitar o falso discurso da educação para a liberdade, tendo em vista que tem-se a proposição de neutralidade e defesa de doutrinação em sala de aula. De forma poética, partindo dos trechos políticos e encantadores da música "Velha roupa colorida" de Belchior onde é pautado a dialética do tempo e da mudança social, percebendo o velho como velho, mas também descartando esse velho em tempos de mudanças significativas, é afirmativo pontuar que o projeto escola sem partido é uma pedagogia ultrapassada, que não nos serve mais, haja vista que a educação está em constante mudança e com um banco de novos sujeitos sociais.

Desse modo, toda essa motriz de discussão apresentada e problematizada no artigo, é de extrema relevância social, política e humana, pois nos mostra uma perspectiva dos reais significados deste projeto. Em tempos de doença social, o texto se constitui conjuntamente com outras epistemologias, dissociando-se desta proposta de (re) colonização por meio da educação, propondo a discussão de forma clara, sucinta e possibilitando uma cura intelectual, educacional e política, levando-se em conta que "a educação é para nós, para nos curar, e não para nos dominar". (GUAJAJARA, 2019, p. 173).

Em suma, o texto segue a discussão dando enfoque no projeto escola sem partido, percebendo as forças reacionárias na construção do Plano Nacional de Educação (PNE), abordando a categoria da ideologia de gênero uma vez que está sendo motivo de discussões e reproduções de ideais conservadores a partir do projeto e dos arautos deste projeto e por fim, trazendo à tona a urgência de debater e compreender este projeto na escola uma vez que há muitas narrativas sendo compartilhadas pelas redes sociais além do debate está pouco inserido no contexto educacional.

\section{Metodologia}

No que tange ao debate sobre o projeto escola sem partido e suas vertentes ideológicas, as propostas metodológicas apontadas para o desenvolvimento da pesquisa acadêmica se instrumentaliza a partir da pesquisa qualitativa de cunho bibliográfica com fundamentação teórica em Freire (2003), Frigotto (2017), Educativa (2016), Cássio (2019), Tonet (2016), Júnior (2020), Gramsci (1985), Saviani (2009), Rios (2011), Junqueira (2018) entre outros autores que alinham o debate e que contribuem significativamente para o desenrolar da 
pesquisa. Desse modo, a pesquisa bibliográfica está listada como a principal ferramenta que possibilita a construção do diálogo com os autores a fim de se ter novas epistemologias que contribua para a formação social e política do leitor.

Assim, é válido pontuar a busca do diálogo com outras bases epistemológicas, pois conforme Gadotti (2010, p. 47) “o diálogo faz parte dessa nossa pedagogia dialógico-dialética, que hoje começa a desabrochar na educação em todo o mundo, renovando a prática pedagógica e dando-lhe um sentido moderno e progressista". Sem dúvidas, a partir de uma imensa revisão bibliográfica, o diálogo se consolida como um instrumento de grande valia para compreendermos a dialética da educação, das políticas educacionais e proporcionar a construção de uma pedagogia que possibilite o empoderamento social e a emancipação. Adicionalmente, Fonseca (2002, p. 31) nos diz que:

[...] qualquer trabalho científico inicia-se com uma pesquisa bibliográfica, que permite ao pesquisador conhecer o que já estudou sobre o assunto (...), procurando referências teóricas publicadas com o objetivo de recolher informações ou conhecimentos prévios, conhecer sobre o problema a respeito do que se procura a resposta.

Logo, é por meio do estudo teórico que tem-se a tentativa de propor uma repolitização quanto as propostas de educação do projeto escola sem partido além de viabilizar uma visão holística das políticas educacionais que estão sendo alijadas esporadicamente pelas políticas de governos. Os caminhos metodológicos da presente produção acadêmica possibilitou a efetivação de novos diálogos de formação tendo em vista que somos seres que se constroem a partir do diálogo uma vez que somos indivíduos essencialmente comunicativos (GADOTTI, 2010). Nesse atual cenário de repressão das políticas educacionais, faz-se necessário cogitar em novas proposições de diálogo para a efetivação de uma educação de qualidade.

Nesse ínterim, tem-se também como recursos metodológicos a pesquisa documental a partir do Projeto de Lei ${ }^{\circ}$ 2474/2014 do deputado estadual Flávio Bolsonaro PSL que institui o programa escola sem partido. As reflexões a partir da leitura do projeto foi de suma importância, onde é perceptível as narrativas conservadoras, subsidiadas por uma política de um partido único ao qual objetiva a emancipação política, a continuidade da pedagogia do exame, da mordaça, da exclusão e a defesa da doutrinação ideológica nas escolas por meio dos professores que discutem temas que devem ser discutidos e que estão intrínsecos a vivência dos aprendizes e presentes em seus territórios, em muitas circunstâncias, áreas desassistidas pelas políticas de governo.

Além disso, utilizou-se do estudo da Lei de Diretrizes e Bases da Educação (LDB), considerando-se as suas concepções, valores e finalidades para a educação brasileira, onde por 
sua vez vai de contraponto aos princípios educacionais do ESP ao firmar a neutralidade política e a farsa do pluralismo de ideias no âmbito acadêmico. Nestas perspectivas, os procedimentos metodológicos possibilitam uma discussão política com reflexões sociológicas e a partir da pedagogia de cunho crítico-social com bem propõe (SAVIANI, 2009).

\section{O Projeto Escola Sem Partido}

Assistimos, a partir dos anos de 2003 até 2015, um quadro político de avanço significativo para com as políticas educacionais em geral com base numa concepção pedagógica de libertação e formação crítica; e recentemente as novas proposições de políticas educacionais com novos recortes de formações, alinhado a pedagogia liberal que se apropria de falsas narrativas de transformação social.

Nesse contexto educacional, o projeto escola sem partido se apresenta como uma vertente da pedagogia tradicional, com base conservadora, ao passo que oportuniza retroceder a educação, sem compromisso com a formação humana e crítica. Atualmente, a sua política ideológica a exemplo da "teoria da conspiração do marxismo cultural e da ideologia de gênero" vem se fortificando e avançando na sociabilidade por meio dos discursos reacionários apelativos e fazendo política contra os planos educacionais de caráter emancipatórios.

A ideologia do ESP é em si uma ideologia que levanta questões e polêmicas ultrapassadas num viés do senso comum com o objetivo de naturalizar o seu posicionamento ideológico e partidário. Pensando nas mídias sociais como reprodutoras da ordem dominante, vê-se que as narrativas do ESP estão sendo vendidas constantemente a sociedade por meio destes aparatos e instrumentos que tornam suas concepções políticas como verdades absolutas.

O ESP objetiva a desconstrução da educação de qualidade que pensa na inserção do sujeito na sociedade como forma de participação social assim como as demais tentativas de coibir o pensamento crítico. "O projeto da Escola sem Partido não é a primeira investida na tentativa de calar ou pelo menos diminuir a possibilidade de debate e de produção de subjetividades singularizadas nas escolas [...]”. (BÁRBARA et al., 2017, p. 116). Nestas perspectivas, a educação proposta pelos aparatos do ESP visa homogeneizar o conhecimento, coibir o pensar de forma crítica e tornar as relações sociais fadadas a reprodução ideológica do sistema capitalista.

A escola nesse sentido é pensada como um lócus de fragmentação do conhecimento e como aparato de alienação social uma vez que não é possível pensar numa politização e nas discussões a níveis de contrapor-se as suas lógicas gerenciais. Assim, o projeto escola sem 
partido busca a legitimação da neutralidade e difunde a ideia da doutrinação ideológica nas escolas por meio de partidos de esquerda.

No entanto, cabe aqui fazer algumas ponderações. É válido afirmar que não há de fato a neutralidade. A própria tentativa de ser neutro já é um posicionamento político a favor da classe burguesa que mantém a educação a partir de relações verticais. Ainda, ressalta-se que a escola não partidariza, mas sim, politiza. É inconcebível pensar a educação sem as proposições políticas e pedagógicas, afinal, como nos diz Rios (2011), a educação tem funções tanto políticas quanto pedagógicas.

Desse modo, “A relação escola-sociedade deve ser analisada de modo crítico para que se evidenciem os mecanismos determinantes da prática educativa. A análise crítica nos levará a constatar a existência de posições diferentes no que diz respeito àquela relação”. (RIOS, 1994, p.47). É significativo perceber o tipo de educação pautado pelo ESP para que se possa confrontar suas bases epistemológicas e atuar frente a hegemonia desta classe que impõe a educação como mão-de-obra para o capital.

Em tempos de obscurantismo da educação em governos neoliberais as ideias do projeto ganham força e procuram novas formas de atuação nos contextos escolares. É visível que a massa social que defende o projeto escola sem partido é, sem dúvidas, indivíduos que prezam pela ESP, o partido com bases no autoritarismo, na reprodução das discussões patriarcais e contra a ascensão social das classes rotuladas como periféricas, marginalizadas e subalternas.

De fato, a política educacional do ESP não está alinhada as perspectivas democráticas de ensino, por isso, não forma sujeitos que possam atuar fortemente na realidade social. $\mathrm{Na}$ verdade, tem-se como proposta pedagógica a ausência do debate, da politização em sala de aula tendo em vista que coloca o professor como ser essencialmente neutro, sem poder problematizar questões pertinentes e necessárias ao cotidiano dos aprendizes e da conjuntura política. Tais ideias ficam explícitas no PL 2474/2014 do então deputado Flávio Bolsonaro, defensor dos valores da família nuclear e a favor das concepções morais ensinadas pelos pais.

Art. $3^{\circ}$. No exercício de suas funções, o professor:

I - não abusará da inexperiência, da falta de conhecimento ou da imaturidade dos alunos, com o objetivo de cooptá-los para esta ou aquela corrente político-partidária, nem adotará livros didáticos que tenham esse objetivo;

II - não favorecerá nem prejudicará os alunos em razão de suas convicções políticas, ideológicas, religiosas, ou da falta delas;

III - não fará propaganda político-partidária em sala de aula nem incitará seus alunos a participar de manifestações, atos públicos e passeatas;

IV - ao tratar de questões políticas, sócio-culturais e econômicas, apresentará aos alunos, de forma justa - isto é, com a mesma profundidade e seriedade - as principais versões, teorias, opiniões e perspectivas concorrentes a respeito; 
V - deverá abster-se de introduzir, em disciplina obrigatória, conteúdos que possam estar em conflito com as convicções religiosas ou morais dos estudantes ou de seus pais.

Por sua vez, o PL aponta claramente que se adequa a reprodução social e as perspectivas de emancipação política da grande burguesia. Ressaltando novamente e em contraponto ao item III do Art $3^{\circ}$, não há de maneira alguma a doutrinação ideológica na sala de aula por meio dos partidos que prezam pelo socialismo e, tampouco a propaganda partidária no debate tecido pelos profissionais da educação em que esta política minimalista criminaliza Freire por sua pedagogia. "Paulo Freire é demonizado como o grande doutrinador - justo ele, que construiu uma obra toda para combater doutrinações”. (MANHAS, 2016, p. 19).

Contudo, tem-se a politização nas perspectivas de ensino democrático. Desse modo, o projeto escola sem partido é uma ferramenta de ataque a escola pública e a classe de professores que visam a emancipação humana. Ainda é viva e cara a existência desta ideologia reproduzida por políticos conservadores, sobretudo, contra as concepções pedagógicas de Freire.

\begin{abstract}
Com a vitória de Jair Bolsonaro, em 2018, as críticas ao educador e ao seu pensamento retornariam de forma contundente. Durante a campanha eleitoral, em agosto daquele ano, em uma palestra para empresários no Espírito Santo, o então candidato afirmaria: "A educação brasileira está afundando. Temos que debater a ideologia de gênero e a escola sem partido. Entrar com um lança-chamas no MEC para expulsar o Paulo Freire lá de dentro". E complementou: "Eles defendem que tem que ter senso crítico. Vai lá no Japão, vai ver se eles estão preocupados com o pensamento crítico". Em seu programa de governo para a educação, Bolsonaro defendeu expurgar o educador das escolas, desta vez com forte apoio das redes sociais, empenhadas em desqualificar e banir o pensamento de Paulo Freire. (HADDAD, 2019, p. 145).
\end{abstract}

Nesse sentido, fica evidente sobre quem são as figuras que estão por trás das concepções políticas e ideológicas do ESP na atual conjuntura educacional e como os arautos desta política pensam na educação e de que forma se responsabilizam pelo ensino e pela qualidade do ensino e aprendizagem. São notórias as críticas a literatura freiriana bem como de outros autores a saber: Marx e Gramsci.

Ainda, as ideias defendidas pelo ESP são visíveis nas manifestações políticas em 2015 a favor do golpe de estado que destituiu a presidenta Dilma Rousseff em 2016. "Entre as palavras de ordem nas manifestações pelo impeachment de Dilma Rousseff, em 2015, uma chamaria a atenção: “Chega de doutrinação marxista, basta de Paulo Freire!”. (HADDAD, 2019, p. 144).

Desse modo, é válido afirmar que o ESP tenta a todo o momento ludibriar o corpo social através do termo "sem" objetivando justificar a neutralidade no campo educacional. No entanto, 
é sabido que suas vertentes tem o partido do autoritarismo como alicerce e, principalmente, reproduzindo sua ideologia por meio de outras linguagens e sentidos.

Ademais, na medida que defendem a neutralidade como possibilidade do ensino justo, igualitário, deixa explícito suas intervenções pretensiosas ao passo que objetivam o alijamento da educação pública, o boicote as políticas sociais de auxílio a população LGBTI+, ferindo os direitos humanos e suas categorias. Por isso, é um projeto inconstitucional, que fere os direitos humanos, atenta a democracia, a dimensão artística, social, cultural e política do ser humano.

Nesse sentido, o movimento ESP vem crescendo em consonância com os grupos fascistas do país desde as movimentações nas redes sociais bem como as representatividades em espaços públicos com ataques ferozes a muitas camadas sociais. Vê-se tal proposição no embate travado por este projeto quanto ao tema da redação de 2015 que pautou a persistência da violência contra a mulher na sociedade brasileira. No sentido educativo e da atuação docente Farias (2006, p. 75) aponta que:

[...] "o professor necessita reconhecer e questionar o ensino como uma construção social, vinculado a interesses de dominação, buscando desenvolver uma ação transformadora frente a esses determinantes. A prática reflexiva crítica é uma postura profissional produzida e expressa a partir do cuidado com a emancipação do outro, do diálogo com os demais colegas e do engajamento do professor com as questões profissionais e sociais que impedem essa emancipação"

O ensino deverá ser ministrado, sobretudo, a partir das concepções plurais, pedagógicas, de garantia da qualidade e da valorização do profissional da educação (BRASIL, 1996). Desse modo, o professor deve politizar e além disso, pensar numa repolitização. Como é sabido, o projeto escola sem partido se habilita a erradicar a doutrinação ideológica no campo educacional. Para tanto "o movimento estabeleceu como estratégia política aprovar leis nos planos nacional, estadual e municipal para vigiar as ações de professores nas escolas, produzindo um clima de perseguição política e de denuncismo". (HADDAD, 2019, p. 145).

Nestas perspectivas, tem-se grandiosas forças reacionárias do ESP apontadas no Plano Nacional de Educação (PNE) como forma de cercear o pluralismo de ideias e a formação crítica, tendo em vista que o PNE objetiva a evolução dos indicadores de analfabetismo, a formação continuada de professores, a valorização do professor e uma gestão democrática entre outros objetivos que dialogam com as políticas de formação social.

Esses pontos apresentam grande relevância social e está em contra mão as perspectivas alienantes do ESP. Infelizmente, a política reacionária do ESP manifesta-se contra as ações propostas pelo PNE dificultando mais ainda a aprovação de ações que são urgentes para a 
educação pública visto que o PNE está assentado em objetivos e metas para com as políticas educacionais.

"É preciso construir uma pedagogia social de cunho crítico que suponha o saber como consciência", afirma Libâneo (2001, p. 54). A educação crítica dever ser defendida como um dos principais recursos educacionais para a difusão do conhecimento. É urgente despertar a educação para a emancipação humana, ou seja, que possibilite a transformação radical da sociabilidade.

"A ideologia tem que ver diretamente com a ocultação da verdade dos fatos, com o uso da linguagem para penumbrar ou opacizar a realidade ao mesmo tempo em que nos torna “míopes.” (FREIRE, 2003, p. 125). A ideologia do ESP é incompatível com a ideologia do exercício democrático, pois está subordinada a educação bancária, sem a problematização e autonomia intelectual do aprendiz. Assim, o projeto escola sem partido usa a escola como espaço educativo de estratégia para impor sua ideologia e expandir outras narrativas contra a educação que problematiza, contra os profissionais que politizam. A exemplo tem-se o debate acerca da ideologia de gênero colocado em pauta como forma de contrapor-se a dimensão do gênero.

\section{Escola Sem Partido: O Debate acerca da Ideologia de Gênero}

Levando em conta a tentativa de homogeneização das relações sociais por meio do ESP, é notório a emergência de um discurso conservador contra a dimensão da natureza humana, principalmente, usando teorias da conspiração para justificar suas epistemologias no âmbito educacional. As proposições de formação curricular deste projeto visa a legitimação de saberes patriarcais, conservadores, a favor da família nuclear e da normatização do papel da mulher na sociedade, tendo em vista que este projeto criminaliza o livro didático por trabalhar temas transversais que são necessários e urgentes na atual conjuntura e que transcendem os espaços de vida.

As temáticas a respeito do racismo, desigualdades sociais e com maior ênfase na perspectiva de gênero são alijadas esporadicamente pelas bases da ideologia do ESP, justamente por contrariar seus horizontes autoritários. Além disso, o professor é tido como doutrinador e disseminador da ideologia de esquerda contra os valores e convicções da família. Dessa forma, o projeto escola sem partido se apropria do debate da ideologia de gênero como forma de atacar o ensino que politiza e como estratégia para reafirmar suas intervenções pretensiosas a favor da classe dominante. Sobre a rubrica do ESP, a ideologia de gênero é uma das teorias das 
conspirações mais usadas para dissociar o debate acerca da categoria de gênero, da identidade e orientação sexual e com a intenção de criminalizar um currículo diverso.

Conforme Adorno (2000, p. 15), "é preciso escapar das armadilhas de um enfoque "subjetivista" da subjetividade na sociedade capitalista burguesa". As armadilhas desta política do ESP culminam na reprodução das desigualdades sociais, na implementação de um currículo que apresenta um cenário político-discursivo antigênero com centralidade em um projeto de poder, naturalizando as relações de gênero e atacando as políticas de equidade de gênero. Assim, o currículo proposto pelo ESP se expressa como ataque a diversidade e ganha projeções contra os direitos sociais da diversidade humana, social e cultural.

A diversidade é um importante componente da humanidade, por isso "ela se faz presente na produção de práticas, saberes, valores, linguagens, técnicas artísticas, científicas, representações do mundo, experiências de sociabilidade e de aprendizagem". (GOMES, 2007, p. 18). Visto a ideologia de gênero como um instrumento de obscurantismo a liberdade de ensinar e contra as problemáticas sociais, filosóficas e políticas, é sabido que essa teoria existe, mas não é como protagoniza os idealizadores e apoiadores do ESP.

Criada com bases na ideologia catequista da instituição Igreja, a ideologia de gênero é sobretudo uma invenção católica que emerge a partir do discurso antifeminista, antigênero e com subsídio nos fundamentos do patriarcalismo nas perspectivas coloniais. Dessa forma, essa teoria é uma das escolhidas pelo projeto escola sem partido para desestabilizar a formação crítica e a educação com fins no debate de gênero e na ressignificação do olhar sobre a diversidade e suas nomenclaturas, apropriando-se da heterossexualidade como doutrina.

Assim, esse rótulo que normatiza as funções femininas e masculinas, é em si, uma categoria política que defende o estado antilaico e um projeto de educação antidemocrática. Não é por acaso que tem-se as mesmas perspectivas de educação assim como as falácias da ideologia sobre os planos educacionais. Objetivando naturalizar o discurso, esse neologismo tenta harmonizar suas concepções ideológicas como crença científica para justificar sua visão moral e política e daí, fazer inversões da realidade.

\footnotetext{
Nesse sentido, eles também atuam em favor da colonização da esfera pública por interesses privados, familistas e religiosos. Isto é algo que se evidencia quando reivindicam a primazia da família na educação dos filhos, e se desdobra em ataques em currículos, à autonomia docente, às políticas inclusivas, às instâncias de administração e regulação da educação, a escolas e docentes em nome de um "direito a uma escola não ideológica", "sem gênero", "sem doutrinação" ou "sem partido". O lema "meus filhos, minhas regras", entoado pelo movimento político reacionário Escola Sem Partido, reitera o familismo e o privatismo dessa ofensiva e parodia o mote "Meu corpo, minhas regras", invertendo o lema feminista pela autonomia e pelos direitos individuais das mulheres e preconizando a submissão absoluta das crianças a seus país. (JUNQUEIRA, 2019. p. 139-140).
} 
Nesta perspectiva, o conceito de gênero é tratado contra os seus limites biológicos além de ser visto como uma categoria que não deve ser interpretada com direitos. Ainda, os arautos do ESP e da ideologia de gênero denuncia os profissionais que discutem os ideais pratriarcais centrados na subordinação da mulher ao homem e ao papel que lhe é imposto justamente por levantar o questionamento sobre o papel da família. A atuação dos diversos grupos religiosos contra a educação crítica é outro setor conservador que legitima a narrativa moralista da ideologia de gênero e do ESP. Por isso, deve-se desfazer os mitos e crenças sobre a diversidade e gênero.

Nesse viés, a ideologia de gênero cumpre um papel essencialmente político, conservador e de apoio a um projeto de poder tradicionalista e, hoje, neoliberal com base nos discursos políticos tirânicos e nas articulações centrais da Igreja como forma de manter a ordem social. Deste modo, é uma ideologia política que se propõe a defender os valores morais da família e de desnaturalizar a visão sobre o corpo, a sexualidade, as diferenças sexuais e em específico ao gênero.

Nesse ínterim, pontua-se que o gênero vai além da concepção biológica, mas é também uma construção social, política e cultural. Infelizmente, as escolas ainda estão fadadas a reproduzir a concepção de gênero abordada nas páginas do livro didático, colocando em xeque, o gênero apenas como sexo biológico, o masculino e o feminino. Partindo de reflexões sociológicas, o gênero é sobretudo uma construção social do sexo com entrelaces na cultura e com total enfoque na dimensão social. Por isso, cabe a nós, entendermos que o gênero perpassa a anatomia de seus corpos.

Nestas perspectivas, o conceito de gênero é também produtos de grandes lutas teóricas e das políticas do feminismo que, em suma, contrapõe-se aos conceitos normativos impostos por instituições conservadoras e pelos rótulos políticos. É válido ressaltar que a categoria gênero é de suma importância para a compreensão das relações de poder e das interações humanas marcadas pela religião, classe, etnia, sexualidade e raça.

Já a identidade de gênero, é a forma como os indivíduos se auto definem, ou seja, independe dos órgãos genitais diferentemente da orientação sexual que diz respeito a questão da sexualidade, do desejo, da atração afetivo-sexual por uma pessoa de algum gênero, seja pela homossexualidade, bissexualidade ou outras orientações. "Nesse sentido, a questão da orientação sexual e da identidade de gênero também ingressa no campo dos direitos humanos e, por conseguinte, no campo da educação. Isso se encontra refletido em legislações federais brasileiras recentes". (REIS, 2017, p. 12). 
Assim, ressalta-se que as políticas de gênero devem ser plenamente efetivadas de modo a construir uma sociedade mais justa e igualitária com a intenção de promover o debate, fomentando as garantias fundamentais e a liberdade, contrariamente à ideologia de gênero que “contribuiu para catalisar estratégias de poder que investem na mobilização da ordem moral e no revigoramento de visões de mundo tradicionalistas". (JUNQUEIRA, 2018, p. 452). A censura educacional promovida pelo ESP em consonância com a retórica antifeminista da ideologia de gênero se manifesta na tentativa de inculcar a diversidade de gênero e suas nomenclaturas, naturalizar a heterossexualização e atribuir valores a família. A título de exemplificação, Junqueira (2019) comenta que, o machismo, a misoginia, a transfobia e o heterossexismo são exemplos claros de manifestações da ideologia de gênero.

Tais manifestações são explícitas nas atuais narrativas de um governo protofascista defensor da necropolítica e da cura gay. Brasil (1996) aponta que, deve-se considerar a educação numa dimensão plural de ensino. Dessa forma, é necessário discutir o racismo enquanto categoria política, equidade de gênero com enfoque na desconstrução dos papeis masculinos e femininos além de dialogar com a comunidade, as bases sindicais e com os movimentos sociais

Em contraponto, há no PL 2474/2014 aspirações contra o docente ao passo que discutese temáticas relevantes como a homofobia e a própria conjuntura política possibilitando reflexões, implicações e indagações já que Freire (2003, p.88) é pontual ao afirmar que "O exercício da curiosidade convoca a imaginação, a intuição, as emoções, a capacidade de conjecturar, de comparar, na busca da perfilização do objeto ou do achado de sua razão de ser".

Sabe-se, no entanto, que a pedagogia tradicional do ESP não possibilita o encorajamento a leitura, a formação política no sentido do empoderamento social e da emancipação. Pelo contrário é uma perspectiva educacional com visões limitadas e com pretensões a domesticação à leitura.

Sabendo disso, urge levar o debate para todos os espaços possíveis, principalmente para a academia e a escola assentada numa gestão democrática e participativa. "Uma vez que a educação é subordinada aos imperativos da reprodução do capital, e uma vez que ela é a matriz da desigualdade social, seria totalmente absurdo esperar que ela pudesse proporcionar a todos uma igualdade de acesso a ela". (TONET, 2016, p. 126).

Portanto, a educação proposta pelo ESP não é viável par romper com as barreiras da alienação, por isso, o debate sobre as concepções políticas e pedagógicas do escola sem partido deve está intimamente ligado a gestão educacional e ao conhecimento dos aprendizes. 


\section{A Urgência do Debate na Escola}

Tendo em conta as teses persuasivas do ESP, faz-se necessário discutirmos suas epistemologias no contexto escolar. Propondo uma analogia ao relembrar a música "velha roupa colorida" do nobilíssimo Belchior, o projeto escola sem partido, felizmente não nos serve mais como proposta educacional de formação cidadã, haja vista as mudanças significativas no campo educacional e no âmbito social, onde, no presente, a mente e o corpo é diferente. Assim como a velha roupa que não nos serve mais, o ESP é uma pedagogia ultrapassada sem sentido para a formação de qualidade. Contudo, é de extrema importância dar vivacidade ao debate tendo em vista a inserção de suas epistemologias nos discursos da atual política neoliberal.

Como nos diz Penna (2017), não cabe nos atermos apenas a inconstitucionalidade do projeto como também perceber suas velhas e novas configurações no cenário educacional. A urgência do debate na escola a respeito desta política reacionária se dar a partir da tentativa de desqualificação do professor, de ferir a ética profissional. Cabe destacar também, as estratégias fascistas que essa pedagogia apresenta além da defesa dos lemas conservadores da ideologia de gênero.

Dito isto, é essencial a desconstrução das armadilhas criadas por este projeto que não apresenta uma dialética de construção humana, mas sim, de transformar a educação em um setor de lucro e de expansão das políticas educacionais neoliberais visto que a educação é percebida como insumo econômico e empresarial.

A escola como um dos principais palcos de formação política, social e humana está corriqueiramente sendo usurpada por esta política, por isso, tem que reagir contra essa mimese da lucratividade. Sem dúvidas, os profissionais enquanto sujeitos políticos e históricos devem tomar posicionamento e politizar no mais alto grau as discussões no que tange essa conspiração fascista que objetiva amordaçar os aprendizes para a manutenção da ordem social. O debate no chão da escola se constitui como um acervo de possibilidades para o desvendar desta cegueira

social e coibir suas práticas educativas. É simbólico discutir e entender os ideais desta problemática educacional proposto pelo partido autoritário assim como levar o debate para outras instâncias sociais.

Reafirmar a importância da escola pública frente a este mecanismo político é algo imprescindível para a manutenção do ensino plural e democrático. "À medida do avanço da sociabilidade, mudam-se os instrumentos e mecanismos de alienação e anulação do pensar crítico para a emancipação". (SOUSA JÚNIOR et al., 2020b, p. 144). 
É nestas perspectivas que as discussões sobre a pedagogia política e pedagógica do ESP é de grande valia para o eixo educacional, em específico, para as escolas que são o lócus de atuação dessa ideologia assentada as sombras de um governo antipovo. A compreensão das lógicas de atuação do projeto nos ajuda a discernir a investida em destituir a pedagogia problematizadora e entender que devemos nos organizar contra os métodos de coação uma vez que objetivamos uma epistemologia de saberes e a socialização destes saberes.

\footnotetext{
A especificidade do processo educativo que se desenvolve na escola reside no fato de que ele tem como objetivo a socialização do conhecimento elaborado - a transmissão do saber historicamente acumulado pela sociedade, que leva à criação de novos saberes. (RIOS, 2011, p. 53).
}

Mesmo diante de pequenas práticas educativas emancipatórias, ainda é urgente a compreensão do ESP no contexto escolar, tendo em vista que esse instrumento de repressão educacional ganhou forças e simpatizantes nesse governo truculento com denominações de apoiadores para as mais variadas funções públicas, principalmente no ministério da educação. Em contrapartida a estas políticas de uma gestão empresarial, é também urgente, reivindicarmos uma formação mais humanística como base nos princípios da escola unitária defendia por (GRAMSCI, 1982).

\section{Considerações Finais}

Nesta produção acadêmica, evidenciou-se algumas considerações sobre a concepção política e ideológica do ESP e os reais objetivos no que tange ao campo educacional. É, em síntese, um projeto político-conservador e partidário sendo divulgado constantemente pelos monopólios de mídia e pelas retóricas discursivas neoliberais.

Fica claro as proposições de criminalização do professor e os trâmites conservadores e patriarcais que os aprendizes devem seguir. De fato, é uma educação tradicional, bancária, que não desperta o pensar crítico já que retrocede as discussões dos temas transversais que são necessários a sociedade.

Infelizmente, é perceptível o alto grau de perniciosidade que o projeto apresenta para as bases educacionais da pedagogia da libertação e da emancipação humana. É notório também a radicalidade de sua política, legitimando propostas conservadoras e hostis. Desse modo, o ESP é literalmente inconstitucional, contra os princípios educacionais e contra as escolas democráticas e da liberdade de ensinar. 
É inegável os interesses políticos, econômicos e sociais por traz de suas epistemologias, visando a emancipação política burguesa. Assim, é um projeto que defende o sucateamento como política pública. Ainda, a criminalização do trabalho pedagógico rumo aos dogmas do autoritarismo, impossibilita a discussão e o entendimento de muitas temáticas que transcendem os espaços de vida bem como as discussões de gênero e orientação sexual.

A invisibilização e a total ausência do debate de temas que são tidos como transversais e que nos são familiar ajuda no aumento gradativo de violações sociais, configurando uma realidade reacionária, obscura e hostil. É visto que as propostas pedagógicas do ESP aponta e legitima o discurso do feminicídio, da lgbtfobia e da desorientação de discussões adjacentes a ao ser social, por exemplo: aumento das DSTs, HIV entre outros debates que devem está incluso em um currículo flexível.

É corriqueiro a criminalização de pessoas, instituições e movimentos sociais que prezam pela equidade social, por isso é necessário a luta constante nas ruas e em todos os espaços educativos. Enquanto profissionais da educação, faz-se necessário se posicionar quanto a barbárie empreendedora do ESP haja vista a despolitização das políticas educacionais. Parafraseando Mario Sérgio Cortela, a omissão, a nossa ausência e o não envolvimento político na educação é literalmente uma ameaça para a escola. Dessa forma, o artigo trouxe a problematização de pedagogia do ESP, possibilitando reflexões necessárias e implicações reflexivo-dialógicas. Portanto, o projeto e suas bases de formação deve ser erradicado nas mais variadas instâncias sociais.

\section{Referências}

ADORNO, Theodor W. Educação e emancipação. Rio de Janeiro: Paz e Terra, 2000.

BÁRBARA, I.S.M.S. Escola sem Partido: visibilizando racionalidades, analisando governamentalidades. In: FRIGOTTO, Gaudêncio (Org.). Escola "sem” partido. Esfinge que ameaça a educação e a sociedade brasileira. Rio de Janeiro: UERJ/LPP, 2017.

BRASIL. Ministério da Educação. Lei n. 9.394, de 20 de dezembro de 1996. Estabelece as Diretrizes e Bases da Educação Nacional. Brasília, 2010. Disponível em: http://www.planalto.gov.br/ccvil_03/Leis/L9394.htm. Acesso em: 10 Fev. 2020.

FARIAS, Isabel Maria Sabino de. Inovação, mudança e cultura docente. In: Os professores e processo de mudança. Brasília: Liber Livro, 2006.

FREIRE, Paulo. Pedagogia da Autonomia. Saberes necessários à prática educativa. São Paulo: Paz e Terra, 2003.

FREIRE, Paulo. Pedagogia do Oprimido. Rio de Janeiro: Paz e Terra, 2014. 
FONSECA, João José Saraiva da. Metodologia da pesquisa científica. Fortaleza: UECE, 2002.

GADOTTI, Moacir. Convite à leitura de Paulo Freire - Pensamento e Ação no Magistério. São Paulo: Editora Scipione, 2010.

Gomes, N. L. (2007). Indagações sobre currículo: diversidade e currículo. Brasília: Ministério da Educação, Secretaria de Educação Básica, 17.

GRAMSCI, Antonio. Os intelectuais orgânicos e a organização da cultura. 1982.

GUAJAJARA, Sônia. Educação indígena: esperança de cura para tempos de enfermidade. In: CÁSSIO, Fernando (ed.). Educação Contra a barbárie: por escolas democráticas e pela liberdade de ensinar. Boitempo Editorial, 2019.

HADDAD, Sérgio. Paulo Freire, o educador proibido de educar. In: CÁSSIO, Fernando (ed.). Educação Contra a barbárie: por escolas democráticas e pela liberdade de ensinar. Boitempo Editorial, 2019.

JÚNIOR, A. R. DE S.; NERI, A. A. M.; MAIA, M. DAS D. A.; JÚNIOR, O. S. A. Os Desafios da conjuntura Educacional à luz do Projeto Escola Sem Partido: Uma análise da formação de Professores de Geografia nos Sertões de Crateús. Revista Homem, Espaço e Tempo, v. 13, n. 2, 12 fev. 2020. Disponível em: http://rhet.uvanet.br/index.php/rhet/article/view/339. Acesso em: 10 Fev. 2020.

JUNQUEIRA, Rogério Diniz. A invenção da" ideologia de gênero": a emergência de um cenário político-discursivo e a elaboração de uma retórica reacionária antigênero. Revista Psicologia Política, 2018, 18.43: 449-502. Disponível em: http://pepsic.bvsalud.org/scielo.php?script=sci_arttext\&pid=S1519549X2018000300004\&lng=pt\&nrm=iso. Acesso:. 10 Fev. 2020.

A "ideologia de gênero" existe, mas não é aquilo que você pensa que é. In: CÁSSIO, Fernando (ed.). Educação Contra a barbárie: por escolas democráticas e pela liberdade de ensinar. Boitempo Editorial, 2019.

LIBÂNEO, José Carlos. Democratização da escola pública. Edições Loyola, 2001.

PENNA, Fernando de Araújo. O Escola sem Partido como chave de leitura do fenômeno educacional. In: FRIGOTTO, Gaudêncio (Org.). Escola "sem" partido. Esfinge que ameaça a educação e a sociedade brasileira. Rio de Janeiro: UERJ/LPP, 2017.

MANHAS, Cleomar. NADA MAIS IDEOLÓGICO QUE “ESCOLA SEM PARTIDO”. In: EDUCATIVA, Ação (Org.). A Ideologia do Movimento Escola Sem Partido: 20 autores desmontam o discurso. São Paulo: Ação Educativa, 2016.

Projeto de Lei Escola Sem Partido $n^{\circ}$ 2474/2014. Disponível em: http://alerjln1.alerj.rj.gov.br/scpro1115.nsf/e4bb858a5b3d42e383256cee006ab66a/45741a7e2 ccdc50a83257c980062a2c2?OpenDocument. Acesso em: 10 Fev.2020.

REIS, Toni; EGGERT, Edla. Ideologia de gênero: uma falácia construída sobre os planos de educação brasileiros. Educação \& Sociedade, 2017, 38.138: 9-26. Disponível em: http://www.scielo.br/scielo.php?pid=S0101-

73302017000100009\&script=sci_abstract\&tlng=pt. Acesso:. 19 Fev. 2020.

RIOS, Terezinha Azerêdo. As dimensões da competência do educador. In: Ética e competência. 20 ed. São Paulo: Cortez, 2011. Cap.3. 
SOUSA JÚNIOR, A. R. de, BEZERRA, M. B. Uma análise pibidiana na obra "pedagogia do oprimido" como possibilidade de empoderamento. In: Editora Poisson. Série Educar- Volume 20 - Políticas Públicas Gestão Escolar - Reflexões. Belo Horizonte: Editora Poisson, 2020. $140 \mathrm{p}$.

Disponível

em:

https://www.poisson.com.br/livros/serie_educar/volume20/Educar_vol20.pdf. Acesso em 11 de março de 2020.

SAVIANI, Dermeval. Escola e democracia. $41^{\circ}$ Edição. 2009.

TONET, Ivo. Educação contra o capital. UFAL, $3^{\circ}$ edição, Maceió: Coletivo veredas, 2016.

\section{Como citar este artigo (Formato ABNT):}

SOUSA JÚNIOR, Arnóbio Rodrigues de; NERI, Antonio Avelar Macedo; MAIA, Maria das Dores Alexandre; BEZERRA, Mayara Barros. Projeto Escola Sem Partido: Uma roupa velha que não nos serve mais. Id on Line Rev.Mult. Psic., Maio/2020, vol.14, n.50, p. 1087-1104. ISSN: 1981-1179.

Recebido: 23/03/2020;

Aceito: 20/05/2020. 